\title{
Students Perception of Entrepreneurship as a Self-Reliance Strategy for Technical and Vocational Education Products
}

\author{
Jane Itohan OviaweAmbrose Alli University, Nigeria; and Ehkovbiye, Osayame Ekhovbiye \\ School of Vocational and Technical Education, College of Education, Igueben, \\ Nigeria.
}

\begin{abstract}
This study examined students' perception of entrepreneurship as a self-reliance strategy for Technical and Vocational Education (TVE) products. The study sample consisted of 960 graduating TVE students from 12 Universities in Southern Nigeria. The findings revealed that creating awareness, stimulating interest and participation in entrepreneurship by TVE students/graduates is a sure way to reducing the ever increasing unemployment of school graduates through self-employment and enhancement.
\end{abstract}

\section{Introduction}

Technical and Vocational Education (TVE) is rather not new in Nigeria. It was incorporated into the Nigerian educational system by the report of the Ashby Commission of 1961. It involves general education and the study of technologies and related sciences as well as the acquisition of practical skills and knowledge relating to occupations designed to produce competent and skilled manpower at all levels of socio-economic occupations including decision-making.

The Federal Republic of Nigeria (FRN), (1981, revised in 1998 and 2004) in her national policy on education emphasizes a strong, united and self-reliant nation with emphasis on the acquisition of TVE that would produce graduates that are sufficiently equipped to work in industries, business, government and also be self employed. To be self reliant, sustained business growth and profitability requires entrepreneurs to exercise the spirit of entrepreneurship. Entrepreneurship addresses the many unstructured and unique issues facing the entrepreneur in an environment of uncertainty. Entrepreneurship enhances self reliance and employment.

However, entrepreneurship requires cultivation and nurturing over time. It cannot be learnt over night. It is a continuous learning and understanding experiences and as such students entrepreneurship potentials needs to be discovered, developed, encouraged and exposed to entrepreneurial culture (Uwameiye, 1994). Entrepreneurship involves setting up a small business quite from obtaining a paid job.

The entrepreneur therefore must organize and manage a commercial undertaking. $\mathrm{He} / \mathrm{she}$ must possess entrepreneurial skills, generate ideas and management skills which are necessary for the success of the business. The United States Colorado Educators for and about business in its position statement in Akinola (2001) defined entrepreneurship education as a programmeme or part of programmeme that prepares individuals to 
undertake the formation and/or operation of small scale enterprise which also includes franchise operations for the purpose of performing all business functions relating to a product or service with emphasis given to the social responsibility, legal requirement and risk for the sake of profit involved in the conduct of a private enterprise.

The education of students should focus not only on teaching the disciplines but also the essence of entrepreneurship. Therefore, entrepreneurship enhances self-reliance and employment. The Nigerian educational sector is made up of pre-school, primary, secondary and tertiary education. Students' involvement in a variety of entrepreneurial activities will enable them to be aware of their vocational preference and attitudes towards certain occupations as they exhibits different abilities, interest, needs, values and attitudes. This exposure will help students ensure that these behaviours are geared in the right direction of occupational selection. Such a career development and awareness should begin from childhood since this is a developmental process that simply does not begin suddenly.

Self-reliance for the individual means self-employment, self-independent and being able to take care of one's problems whether socially or economically relying on one's skills, abilities and competences to earn a living. For a nation like Nigeria, self-reliance means being able to take care of its citizens, relying mainly on its internally produced goods and services; it means that it is socially politically and economically dependent on its resources with minimal or no foreign aid. But this is truly not the case in most third world countries including Nigeria.

Studies conducted by the Federal Office of Statistics FRN (1990) reveled that a major source of rate of unemployment is the increasing migration of people especially youths from rural to urban areas in search of white-collars-jobs; in addition to the large turnout of school leavers and graduates. The implementation of economic/monetary policies such as the Structural Adjustment Programmeme (SAP) had also caused the retrenchment of labour as part of the cost of economic reforms. Unemployment is a very serious problem facing Nigeria today. To this end, Akinola (2001) advised that it is most appropriate to educate thousand of the youths (students and graduates inclusive) on how to start their own business right from school. Students and TVE products should be able to display competence and skills for possible self-reliance and employment in entrepreneurship. This will increase the production and provision of goods and services, revenue generation and national growth.

And although several financial policy statements and directives of the Federal Government of Nigeria including annual budgetary statements are clear indications of government supports for entrepreneurship, unfortunately, it is arguable that even in dedicated entrepreneurship courses, the real essence of entrepreneurship is hardly taken seriously. To Lassa (1997), entrepreneurship education is rarely emphasized in most tertiary institutions.

\section{Statement of the Problem}

Successive government in Nigeria through different policy statements and programmemes (such as Operation Feed the Nation (OFN), Green Revolution (GR), Structural Adjustment Programmeme (SAP), Directorate for Food, Road, and Rural Infrastructure (DFRRI); National Directorate of Employment (NDE) among others) had tried in several ways with the intent of stimulating self-reliance culture and development of the private sector 
through the participation of its citizens in entrepreneurial ventures. These laudable ideas had not been fully achieved in view of the ever-increasing rate of unemployment. Against the backdrop of the government funding of TVE programmemes and the high level of unemployment of youths which may have brought about the need for other sourcing of income generation entrepreneurial ventures, Ojukwu (2001) advised that students and TVE products must be properly educated on why they have to take a serious look at entrepreneurship as a self-reliance and employment strategy. But this has not received the much needed attention and as such inadequately utilized. TVE students/products involvement in entrepreneurship is currently inadequate, low or even non-existent in most institutions in Nigeria (Ojukwu, 2001). Lassa (1997) reported that this may be due to the fact that entrepreneurship education and entrepreneurship is rarely emphasized in most tertiary educational institutions. The problem of this study is that products of TVE do not seem to be engaged in entrepreneurial ventures after graduation.

\section{Purpose of the Study}

To determine TVE students perception of entrepreneurship as a self-reliance strategy; and ascertain whether TVE products are equipped with relevant knowledge, skills, and competence to manage small-scale business.

\section{Methodology Research Design}

The research design is a descriptive survey on students' perception of entrepreneurship as a self-reliance strategy for TVE products.

\section{Population and Sample for this Study}

The population for this study consisted of all (31) Public Universities in Southern Nigeria. Out of these 31 public Universities, only 17 offer TVE Programmemes in Agricultural Education; Business Education; Home Economics Education and Technical Education. Out of the 17 public Universities, 12 were randomly selected using the simple balloting technique. The sample consisted of 960 TVE students randomly selected from the 12 institutions, that is, 80 students from each University. Of the 960 students, 720 were males and 240 females.

\section{Instrumentation}

The only instrument used in this study was a 20 item questionnaire derived from literature and titled: "Students Perception of Entrepreneurship as a Self-reliance Strategy for TVE Products Questionnaire (SPESSTVEPQ)". Respondents were asked to rate each of the items on a four-point scale as follows: Strongly Agree (SA)-4; Agree (A)-3; Disagree (D)-2; and Strongly Disagree (SD)-1. The instrument was validated by three experienced research scholars in the field of TVE from the University of Benin, Benin City, Ambrose Alli University, Ekpoma and Delta State University, Abraka. Their suggestions and corrections resulted in the final draft used for this study.

A pilot group of 30 TVE students from a University in Southern Nigeria, within the target group but not included in the main study was arranged for deriving the reliability for the study. A split-half method using the Spearman's Brown Prophecy formula was used to correlate the data generated. The reliability index of 0.83 was obtained. On the whole, 960 
questionnaires that formed 100 per cent return rate, was obtained and used to carry out the analysis.

\section{Data Analysis}

The data gathered from this study were analyzed using mean (X), Standard Deviation (SD) and t-test statistics. For research question one, the mean and standard deviation were used as statistical tools. The mean of 2.5 was taken as the critical value for decision such that a mean response that falls below 2.5 was regarded as 'Agreed' while a mean response on or above 2.5 was regarded as 'Disagreed'. The hypothesis was tested at 0.05 level of significance such that any calculated t-test value less than $1.96(\mathrm{P}<0.05)$ was regarded as "insignificant" and any calculated t-test value above 1.96 at 0.05 level of significance $(\mathrm{P}>0.05)$ was regarded as "significant".

\section{Findings}

Research Question: What are the perceptions of TVE students of entrepreneurship as a self-reliance strategy for TVE products?

Table 1: Mean and standard deviation scores on students perception of entrepreneurship as a self-reliance strategy for TVE.

$\begin{array}{lllll}\mathbf{S} / \mathbf{N} & \text { Items } & X & \text { SD } & \text { Decision }\end{array}$

1. I prefer business/self employment as a profession after leaving school.

2. I prefer teaching (public/private) and other paid employment as a profession after leaving school.

3. Whatever is the chosen profession (if other than business) business is a likeable second choice.

$3.66 \quad 0.71 \quad$ Agree

$2.45 \quad 1.06 \quad$ Disagree

$3.10 \quad 0.90 \quad$ Agree

4. Entrepreneurship is a worthwhile venture regardless of ones chosen profession.

5. Entrepreneurship is a viable venture that serves as a self-reliance strategy for TVE products.

6. Entrepreneurship education in my course of study is very high and encourages viability of small scale business

7. I would like to own a business and be an employer of labour.

8. Industrial training and work-visit impact and stimulate interest in entrepreneurship.

$3.12 \quad 1.05 \quad$ Agree

$3.10 \quad 0.99 \quad$ Agree

$2.16 \quad 1.01 \quad$ Disagree

$2.86 \quad 0.89 \quad$ Agree

$2.88 \quad 0.79 \quad$ Agree

9. Participation in business inclined association like Young Farmers Club encourages and stimulates interest towards entrepreneurship.

$2.19 \quad 1.11 \quad$ Disagree

10. TVE provides the enabling environment to acquire the necessary skills and competencies required for entrepreneurship

$2.84 \quad 0.89 \quad$ Agree

11. Entrepreneurship education creates awareness and stimulates interest in entrepreneurship.

$3.12 \quad 0.92 \quad$ Agree


12. Instruction placing emphasis on the use of practical demonstration; use of case studies; discussion; and workshops help motivate interest in entrepreneurship.

$3.05 \quad 0.90 \quad$ Agree

13. The use of role models; personalities in leadership positions and business involvement in instructions create a psychological learning environment and build up confidence in entrepreneurship.

$2.96 \quad 0.87 \quad$ Agree

14. More involvement of a greater number of TVE products in entrepreneurial enterprise is needed.

15. TVE products are equipped with necessary skills and competence to manage entrepreneurial $\mathrm{v}$ entures.

16. They also show exemplary skills and competence in whatever assignments and jobs given them.

17. Given the support, entrepreneurship serves as self reliance avenue for the employment of TVE products.

$3.21 \quad 0.91 \quad$ Agree

18. Government support and provision of enabling environment for entrepreneurship development is significant and adequate.

$1.91 \quad 0.61 \quad$ Disagree

19. Most organization allows for TVE students industrial training and exposure to entrepreneurship.

20. There is a closer tie between the TVE and the world of work (theory and practice).

$1.81 \quad 0.65 \quad$ Disagree

$1.92 \quad 0.63 \quad$ Disagree

In response to research question 1 , table 1 shows that the respondents rated 13 out of the 20 items as agreed while the other 7 items were rated as areas where they disagreed. The implication of this is that TVE students prefer business/self employment after leaving school; Entrepreneurial ventures serves as a self reliance strategy for TVE products; TVE provides the enabling environment to acquire the necessary skills and competencies required for entrepreneurship; and TVE products are equipped with the necessary skills and competence to manage entrepreneurial ventures.

Hypothesis: There is no significant difference between male and female students perception of entrepreneurship as a self-reliance strategy for TVE products. 
Table 3: t-test of significance difference between ale and female TVE students on their perception of entrepreneurship as a self reliance strategy for TVE products.

\begin{tabular}{|c|c|c|c|c|c|c|}
\hline $\mathbf{S} / \mathbf{N}$ & Male T & Idents & Fema & E students & Calculated & Criterion \\
\hline N1 & X1 & SD1 & $\mathbf{N 2}$ & $\mathbf{X} 2$ & SD2 t-test Value & $\begin{array}{l}\text { t-test } \\
\text { Value }\end{array}$ \\
\hline
\end{tabular}

$\begin{array}{lllllllll}\text { 1. } & 720 & 3.68 & 1.03 & 240 & 3.64 & 1.08 & 0.55 & 1.96 \\ \text { 2. } & 720 & 2.48 & 0.98 & 240 & 2.42 & 0.90 & 0.44 & 1.96 \\ \text { 3. } & 720 & 3.12 & 0.80 & 240 & 3.08 & 0.63 & 0.80 & 1.96 \\ \text { 4. } & 720 & 3.09 & 1.00 & 240 & 3.15 & 0.91 & 0.87 & 1.96 \\ \text { 5. } & 720 & 3.12 & 0.65 & 240 & 3.08 & 0.63 & 0.89 & 1.96 \\ 6 . & 720 & 2.22 & 0.78 & 240 & 2.10 & 0.77 & 2.18^{*} & 1.96 \\ 7 . & 720 & 2.84 & 1.03 & 240 & 2.89 & 0.83 & 0.71 & 1.96 \\ 8 . & 720 & 2.90 & 0.91 & 240 & 2.86 & 1.11 & 0.86 & 1.96 \\ 9 . & 720 & 2.44 & 0.74 & 240 & 1.94 & 0.81 & 9.43^{*} & 1.96 \\ 10 . & 720 & 2.90 & 0.43 & 240 & 2.78 & 1.03 & 3.00^{*} & 1.96 \\ 11 . & 720 & 3.09 & 1.12 & 240 & 3.15 & 0.91 & 0.75 & 1.96 \\ 12 . & 720 & 3.03 & 0.67 & 240 & 3.07 & 0.53 & 0.89 & 1.96 \\ 13 . & 720 & 2.99 & 0.81 & 240 & 2.93 & 0.98 & 1.00 & 1.96 \\ 14 . & 720 & 3.20 & 0.96 & 240 & 3.22 & 0.83 & 0.31 & 1.96 \\ 15 . & 720 & 3.20 & 1.01 & 240 & 3.28 & 0.65 & 1.23 & 1.96 \\ 16 . & 720 & 2.38 & 0.86 & 240 & 2.10 & 0.95 & 4.67 * & 1.96 \\ 17 . & 720 & 3.23 & 0.94 & 240 & 3.15 & 0.90 & 1.23 & 1.96 \\ 18 . & 720 & 1.95 & 0.99 & 240 & 1.87 & 1.01 & 1.14 & 1.96 \\ 19 . & 720 & 1.84 & 1.11 & 240 & 1.78 & 0.98 & 0.79 & 1.96 \\ 20 . & 720 & 1.95 & 0.99 & 240 & 1.89 & 1.01 & 0.86 & 1.96\end{array}$

*Significant

Table 2 indicates that 4 out of the 20 items had calculated t-test value above the criterion t-test value of 1.96 at the 0.05 level of significance. Thus, the null hypothesis of no significant difference is rejected and the alternate hypothesis is retained. Table 2 also reveals that the calculated t-test values for 16 out of the 20 items had t-test values less than the criterion t-test value of 1.96 at 0.05 level of significance. Therefore, the null hypothesis of no significant difference between the mean rating of perception of male TVE students and their female counterparts of entrepreneurship as a self-reliance strategy for TVE products is retained. This means that there is no significant difference between male and female students perception of entrepreneurship as a self-reliance strategy for TVE products.

Discussion of Findings

Result in Table 1 indicates that graduating TVE students preferred business/self employment after leaving school; that entrepreneurial ventures is a viable tool that serves as a selfreliance strategy; and that TVE provides the enabling environment and equips its products with necessary skills and competencies for entrepreneurship. The responses from the subjects to items $3,7,8,9,11,12,13,14$, and 17 showed that TVE enhances and stimulates interest in entrepreneurship. This finding is in line with Lassa (1997) and Ojukwu (2001), who reported that TVE students must be taught how to start and run entrepreneurial 
ventures since they are enterprising in nature whether as employees, employers or self employed in view of its training curricular and exposure to the world of work.

Table 2 reveled that there is no significant difference (in 16 out of the 20 items) between the perception of male and female students of entrepreneurship as a self reliance strategy for TVE products. Kanu (1994) and Fajana (2002) support the finding of this study when they reported that male and female students' perception and attitude had no significant difference in entrepreneurship operation. Thus the null hypothesis for these items is retained. Table 2 also revealed that a significant difference does exist for items 6 , 9, 10 and 16. This may not be unconnected with the number of females to males' students' ratio and the poor manifestation of entrepreneurial exposure given to students.

\section{Conclusion and Recommendations}

The ever increasing rate of unemployment has had impact on government decisions in recent time. The incorporation of TVE into Nigerian educational system was aimed at equipping the student individual and products of the system with necessary skills and competencies for self reliance and national development. The findings of this study revealed that TVE students' perceived entrepreneurship is viable for reducing unemployment through participation and that the programmeme had equipped the students with skills and abilities for managing entrepreneurial ventures. This study thus recommends that training workshops and seminars should be organized to create awareness and also help re-orientate TVE products of the entrepreneurial opportunities and benefits in TVE. public enlightenment and awareness programmemes should be created to products/graduates of TVE on the importance and benefits of entrepreneurial education to TVE products using available media such as posters, hand bills, Radio and Television shows, public lectures and conferences under the forum of existing entrepreneurs/professionals to stimulate participation self-reliance/employment; andprofessional entrepreneurs should be invited to give career-talks, and serve as role models/teachers to create awareness to TVE products in schools.

\section{References}

Akinola, C.I. (2001). Teaching entrepreneurship skills through Business Education: The challenges and strategies for Business Educators. In: Aromolaran, A. (Ed.). Business Education Journal. III (4).

Fajana, S. (2002). Moonlighting among graduates in Nigeria. The Journal of Educational Research and Development. 6 (1). 1-14.

Federal Republic of Nigeria, (2004). National Policy on Education. Lagos: NERDC Press.

Federal Republic of Nigeria, (1990). Achievements of the Federal Ministry of Employment,

Labour and Productivity under the Babangida Administration. Planning Research and Statistics Department. (1985 - 1990). Lagos: Government Press. 8 - 11.

Kanu, I. N. (1994) Promote Self reliance of Youth School Leavers through entrepreneurship skills and competencies. Asaba. A paper presented at the 9th Annual National Conference of the Nigerian Association of Business Educators (NABE), Federal College of Education (T).

Lassa, P. N. (1997) Entrepreneurship Education for Socio-economic and Industrial Development. Umunze A keynote address presented at the National Conference on Entrepreneurship Education held at Federal College of action (Tech)

Ojukwu, K. (2001) "Factors Affecting Entrepreneurship Involvement by Vocational

Business Department in Nigeria: Implications for Curriculum and Pedagogy". In Aromolaran, A. (Ed.) Business Education Journal. 3 (4). 